\title{
Effect of Nutrition on Toxicity of Contaminants to the Epibenthic Amphipod Melita plumulosa
}

\author{
D. A. Spadaro $\cdot$ T. Micevska $\cdot$ S. L. Simpson
}

Published online: 18 September 2008

(C) Springer Science+Business Media, LLC 2008

\section{Erratum to: Arch Environ Contam Toxicol} DOI 10.1007/s00244-008-9153-2

In this article the second sentence of paragraph 3, page 6 should read as "For zinc, 10-day $\mathrm{LC}_{50}$, LOEC and NOEC values of 220 (190-260), 180 and $90 \mu \mathrm{g} \mathrm{Zn} / \mathrm{L}$ were determined, respectively."

The online version of the original article can be found under doi:10.1007/s00244-008-9153-2.

D. A. Spadaro - T. Micevska · S. L. Simpson ( $₫)$

Centre for Environmental Contaminants Research, CSIRO Land and Water, Private Mailbag 7, Bangor, NSW 2234, Australia

e-mail: Stuart.Simpson@csiro.au 